\title{
Fokus
}

\section{Die Psalmboek van 2003 as bron van liturgiese verryking}

\author{
H.J. Jankowitz \& D. Kruger \\ Fakulteit Lettere en Wysbegeerte \\ Potchefstroomkampus \\ Noordwes-Universiteit \\ POTCHEFSTROOM \\ E-pos: 3kie@iway.na \\ daleenkruger@nwu.ac.za
}

\begin{abstract}
The Psalmbook of $\mathbf{2 0 0 3}$ as a source of liturgical enrichment

The aim of this article is to bring to view some liturgical possibilities made available through the Psalmbook of 2003. One of the objectives of this intensively revised volume was to expand and enrich the liturgy through congregational singing. New psalm melodies, newly-versified Scriptures set to well-known tunes, as well as psalms set to favourite "Liederwysies", will contribute to a newly-illuminated metalanguage of liturgical song.
\end{abstract}

All examples of songs for the different elements of the liturgy are mainly proposed to serve as a starting point for further creative development. Psalms and Scriptural versifications are suggested for suitable liturgical responses. Especially targeted are liturgical elements where the liturgist speaks on behalf of the congregation. In these instances a selection of songs is given which congregations could utilise as part of an active liturgical dialogue instead of being passive audiences.

This article could also serve as a reference document for organists and liturgists when planning a church service. To enhance user-friendly utilisation as well as creativity, a variety of liturgical possibilites are presented according to the commonly used liturgical order of reformed church services. 


\section{Opsomming}

\section{Die Psalmboek van $\mathbf{2 0 0 3}$ as bron van liturgiese verryking}

Die doel van hierdie artikel is om sommige verrykende, liturgiese moontlikhede, wat deur die Psalmboek van 2003 beskikbaar gemaak word, onder die aandag te bring. Een doelwit van hierdie hersiene en uitgebreide liedere was juis om "verruiming en verryking in die liturgiese sangaktiwiteit" moontlik te maak. Die nuwe psalmmelodieë en tekste, toevoegings van Skrifberymings op bekende melodieë, saam met psalms op geliefde liederwysies, sal tot 'n meer diepgaande, meelewende liturgiese sang kan bydra.

Die verskillende voorbeelde van liturgiese liedere word voorgestel om as basis vir verdere kreatiewe, liturgiese ontginning te dien. Psalms en Skrifberymings wat vir liturgiese response gebruik kan word, word voorgestel. Hier word veral liturgiese elemente in die erediens, waar die liturg gewoonlik namens die gemeente antwoord, geteiken. 'n Keur van geskikte liedere word aangebied om hierdie elemente aan die gemeente terug te gee, sodat gemeentelede deel van 'n aktiewe liturgiese dialoog, in plaas van passiewe toehoorders kan wees.

Verder kan hierdie artikel by uitstek as naslaanhulp vir orreliste, liturge of liturgiese werkgroepe by die beplanning van 'n erediens dien. Om gebruikersvriendelike sowel as kreatiewe funksionaliteit te bevorder, word 'n verskeidenheid liturgiese moontlikhede onder die algemeen gebruiklike liturgiese afdelings ingedeel.

\section{Inleiding}

'n Erediens kan omskryf word as 'n godvererende, koinoniaalkorporatiewe ontmoetingsgeleentheid tussen God en sy verbondsgemeente (Strydom, 1994:157-161; Vorster, 1996:85-87). In die liturgie van die erediens word 'n stelselmatige gespreksontplooiing tussen God en die gemeente vergestalt. ${ }^{1}$ Wanneer hierdie ontmoetingsgebeure 'n eiesoortige stylpatroon ontwikkel of slegs in sekere liturgiese gebruike vasval, bestaan die moontlikheid dat lewenskragtige, gemeentelike deelname ingeboet word weens 'n behoefte aan sinvolle afwisseling of die passiwiteit van die gemeente. Sonder voortdurende vernuwing, kan die erediens dus stagneer in betekenislose formalisme. Daarom behoort die aktiewe 
betrokkenheid en geestelike belewing van die gemeente by die beplanning van 'n erediens in ag geneem te word (Vorster, 1996: 105-106).

Gemeentesang is by uitnemendheid 'n uiters geskikte, responsoriese voertuig tydens die erediens. Nuwe, liturgiese liedere en meer liturgiese moontlikhede is deur die Psalmboek van 2003 beskikbaar gemaak. Hierdie bundel ontsluit dus aanvullende wyses waarop die liturgie verruim en verryk kan word tot meer meelewende deelname. Dit word in die voorwoord tot die bundel soos volg verwoord:

Hiermee word die uitgebreide liedereskat van die GKSA varsgebundel aangebied. Dit wil liturgiese liedere in ou én nuwe vorme (taal- en melodies gesproke) op die liturgievierende tong van die gemeentes plaas. ... Die aanvulling wil eerder verruiming en verryking in die liturgiese sangaktiwiteit van die geloofsgemeenskap in die hand werk. (Bingle, 2003: Voorwoord.)

Voortvloeiend uit hierdie uitgangspunt, word dit nodig om alle psalms en Skrifberymings te ondersoek om hulle maksimale liturgiese moontlikhede te ontdek. Alle liturgiese elemente word dan vanuit hierdie gesigspunt heroorweeg ten opsigte van optimale, godverheerlikende, gemeentelike deelname.

Ter wille van 'n gebruikersvriendelike en praktiese aanbieding, word alle moontlike liturgiese elemente soos volg verduidelikend aangebied: onder die ontmoetingsdiens sorteer die voorbereiding tot die erediens, die votum, die groetseën en die loflied; as deel van die verootmoedigingsdiens word die skuldbelydenis, die vryspraak, die loflied na die vryspraak en die wet geplaas (vgl. ook 2.4); die Woorddiens bestaan uit die gebed om verligting deur die Heilige Gees, die Skriflesing, die preek en die preeklied en/of slotlied; die sakramente, indien dit bedien word, volg gewoonlik na die preek; die antwoorddiens van die gemeente behels die geloofsbelydenis, die voorbiddingsgebed en die offergawes; ten slotte kan die wegsending uit die wegsendingslied, die seën en die amen bestaan (Müller, 1988:52-104; Strydom, 1994:294-301; Vorster, 1996:93-105 en GKSA, 1997).

Om te onderskei tussen die verskillende berymings of omdigtings by 'n spesifieke psalm, word die verskillende digters soos volg aangedui: Du Toit $($ Totius $)=-1$, Cloete $=-2$, Spies $=-3, \mathrm{Krog}=-4$ en Breytenbach $=-5$. Waar meer as een melodie by 'n psalm afgedruk is, word die voorkeurmelodie soos volg tussen hakies aangedui: Ps. 107(1). 
Weens die toenemende ekumeniese gebruik daarvan, word die Latynse benamings uit die ordinarium van die mis as wisselterme gebruik (Kloppers, 1998:22-24 en Chantz de Taizé, 2001: Indeks). Hierdie liturgiese tekste dateer oorspronklik uit die heel vroeë liturgiegeskiedenis, meestal as aanhalings uit die Bybel: Kyrie eleison, Gloria, Credo, Sanctus en Agnus Dei (Strydom, 1992:11).

\section{Die benutting van die Psalmboek van 2003}

Die doel van hierdie artikel is om liturgiese funksionaliteit nuut te belig vanuit die moontlikhede wat deur die Psalmboek van 2003 beskikbaar gemaak word. Sodoende kan 'n bydrae gelewer word dat hierdie liedere liturgies meer doelmatig, variërend en meer dikwels per erediens aangewend kan word.

Geskikte, gesonge, liturgiese response in antwoord op God se spreke word aan die hand gedoen. Verder word veral liturgiese elemente, waar die liturg namens die gemeente aan die woord is, geteiken. By hierdie elemente word 'n keur van liedere gegee wat deur die gemeente, as deel van 'n aktiewe liturgiese dialoog, gesing kan word. Dit kan daartoe bydra dat die gemeente met meer begrip en meelewing aan die erediens kan deelneem. Aangesien hedendaagse liturge en musiekleiers toenemend onder druk verkeer om 'n verskeidenheid "verwagtings" of spirituele style binne 'n erediens te akkommodeer (Kloppers, 2002:12-13), bied die nuut toegevoegde woorde en melodieë juis ' $n$ breër keuse - waar dikwels ' $n$ meer eietydse idioom deur 'n toegankliker spreektaal en melodiese styl verteenwoordig word.

Ten opsigte van enige liturgiese voorstelle wat vreemd vir 'n gemeente is, of waar die volgorde van liturgiese elemente verskillend aangebied word, is dit noodsaaklik dat versigtig te werk gegaan word. Die gemeente behoort stelselmatig begelei te word tot 'n meer betekenisvolle, liturgiese dialoog deur middel van goedbegronde, kwaliteit-kommunikatiewe voorstelle en 'n sensitiewe aanvoeling vir die behoeftes van die gemeentelede. Liturgie in wêreldwye, gereformeerde kerke, asook in Suid-Afrika, beleef tans 'n lewenskragtige ontwikkelingstydperk sodat die volgorde in verskillende gemeentes kan verskil. 2 Die volgorde wat in hierdie artikel gevolg word, behoort dus aangepas te word by die individuele gemeentelike praktyke.

2 Die vroeë, Nederlands-gereformeerde liturgie (soos aan die Kaap voortgesit) is deur die meeste Afrikaanse gereformeerde kerke oorgeneem. Gedurende die twintigste eeu het die liturgie egter al meer in ooreenstemming gekom met 
Psalms kan op verskillende maniere kreatief in die erediens aangewend word. Sommige aanwendingsmetodes, wat kan bydra om die betekenis van 'n besondere psalm opnuut te belig, word hier uiteengesit.

- Die psalm word afwisselend voorgelees (nie noodwendig deur die liturg nie) en deur die gemeente gesing. Voorbeelde hiervan is die volgende:

- Psalm 66-1 gemeentesang strofes 1 tot 2; Skriflesing verse 8 tot 12; gemeentesang strofe 6; Skriflesing verse 16 tot 17; gemeentesang strofe 8; Skriflesing vers 20 .

- Psalm 108-2 gemeentesang strofe 1; Skriflesing verse 3 tot 5; gemeentesang strofe 3; Skriflesing verse 11 tot 13; gemeentesang strofe 8 .

- Psalm 125-2 gemeentesang strofe 1; Skriflesing vers 2; gemeentesang strofe 3; Skriflesing verse 4 tot 5; gemeentesang strofe 4 .

- Psalm 139-3 gemeentesang strofe 1; Skriflesing verse 7 tot 12; gemeentesang strofe 3; Skriflesing verse 16 tot 18; gemeentesang strofe 5 .

- Die psalm word in die vorm van 'n liturgiese dialoog gebruik. Dié gedeeltes van die psalm wat in die vorm van 'n gebed aan God gerig is, word deur die gemeente gesing en dié gedeeltes wat as onderwysing bedoel is, word deur die liturg of liturgiese koor gelees of gesing. Hierdie metode, sowel as die bostaande, kan plaasvervangend vir die Skriflesing gebruik word. Voorbeelde ter verduideliking:

- Psalm 9-1 gemeentesang strofes 1 tot 3; liturg strofes 4 tot 6; gemeente strofe 7; liturg strofe 8; gemeente strofes 9 tot 10; liturg strofes 11 tot 14; gemeente strofe 15.

- Psalm 48-2 liturgiese koor plus gemeente strofe 1; liturg strofe 2; gemeente strofe 3; liturg of liturgiese koor strofe 4 met die gemeente wat aansluit by die laaste 2 reëls van die strofe.

Calvyn se oorspronklike, Straatsburgse uiteensetting daarvan (Strydom, 1994:68, 103). 
- Psalm 66-2 gemeente strofe 1; liturg strofe 2; liturgiese koor strofe 3; gemeente strofe 4 .

- Psalm 75-1 gemeente strofe 1; liturg strofe 2; liturgiese koor strofe 3; liturg strofe 4; liturg plus liturgiese koor strofe 5; liturgiese koor plus gemeente strofe 6 .

- Ondersoek in hierdie verband ook die moontlikhede van die volgende: Psalm 10, 18, 27, 32, 38, 39 en 84.

- Uitgesoekte psalms kan as sentrale, liturgiese bron vir 'n erediens aangewend word. Verskillende verse uit die lied word by sekere elemente gebruik. Psalms wat hulle onder andere spesiaal tot hierdie doel leen, is Psalm 5, 9, 27, 32, 66 en 116. 'n Paar van hulle word hier as voorbeelde uiteengesit:

- Psalm 5-1 votum strofe 6; oproep tot skuldbelydenis strofes 4 tot 5; boetedoening strofe 2; vreugde na vryspraak strofe 10; aanhef van gebed strofe 1; offergawe strofe 3; wegsending strofe 7 ; seën strofe 11 .

- Psalm 5-2 intoglied strofe 3; oproep tot skuldbelydenis strofe 2; vreugde na vryspraak strofe 5; aanhef van gebed strofe 1.

- Psalm 9-1 lof strofes 1 en 8; aansluitend by die wet strofe 12; Kyrie eleison strofe 9; vreugde na vryspraak strofe 10; geloofsbelydenis strofe 7 .

- Psalm 27-3 bedevaartslied strofe 3; lof strofes 1 tot 2; epiklesegebed strofe 5; geloofsbelydenis strofe 6; aanhef van hoofgebed strofe 4.

- Psalm 116-2 lof strofes 1 en 7; troos van vergifnis strofes 3; aansluiting by gebed strofe 2; geloofsbelydenis strofe 4 ; dankoffer strofe 5; wegsending strofe 6 .

Indien 'n psalm volgens bogenoemde wyse aangewend word, terwyl dieselfde Psalm of ' $n$ gedeelte daaruit terselfdertyd as preekonderwerp gekies word, kan dit aan die erediens 'n eenheid en sentrale fokuspunt verleen.

Kloppers (2002:18) gee 'n treffende uitbouing van 'n sentrale, liturgiese tema deur gebruikmaking van kort Skriflesings uit die 
psalms in afwisseling met aansluitende Taizé-liedere. Omdat baie Taizé-liedere op psalms gebaseer is, kan hierdie metode met groot vrug wyer aangewend word.

\section{Ontmoetingsdiens (Introïtus)}

\subsection{Voorbereiding}

Voorbereiding tot die erediens is noodsaaklik om die gemeente daarop in te stel om op God te fokus; dit is veral nodig te midde van die eietydse, gejaagde lewe. Gemeentesang, waarin die tema van die erediens beklemtoon word, kan as goeie voorbereiding gebruik word. Die aanleer en hersiening van psalms behoort veral aandag te geniet by die voorbereidende gemeentesang. Daar is moeite gedoen om meer "singbare" melodieë te soek en te gebruik. Van die Cloete-omdigtings is daar 60 psalms met wysies wat makliker toeganklik vir die "kerkvolk" behoort te wees. Die nuwe Afrikaanse psalmomdigtings verskyn saam met nuutgekomponeerde melodieë - melodieë oorgeneem van ander hoofstroom denominasies asook bekende gesang- of liederwysies. Nuwe Skrifberymings op bekende melodieë kan die Nuwe-Testamentiese perspektief verbreed. Die gesamentlike toevoegings kan daartoe bydra om 'n nuutbeligte metataal of lyftaal van liturgiese sang te ontplooi (Bingle, 2003:XIII).

As afsluiting van die voorbereidende gemeentesang, kan 'n toetredelied, intoglied of bedevaartslied gebruik word om die afwagting vir die erediens of die verlange na die ontmoeting met God, te beklemtoon (Strydom, 1994:306 en Troskie, 2001:29). Die volgende psalms kan oorweeg word: Psalm 5-1:6; 5-2:3; 26-1:5; 26$2: 3$; 27-1:2, 4; 27-2:4; 27-3:3; 42-1, -2,- 3:1, 2; 43-1:4; 43-2:2; 61$2: 2 ; 63-2: 1 ; 84-1,-2 ; 100-1,-2: 1,3 ; 118-2: 5,7 ; 122-1: 1$ of 132-1:5.

\subsection{Votum}

Aangesien die gemeente by die votum aan die woord is, behoort die gemeente soveel as moontlik as gespreksgenoot betrek te word. Die volgende beklemtonings is gebruiklik: die ontmoeting tussen God en sy gemeente, 'n Trinitariese verklaring dat die erediens in die Naam van God plaasvind, ' $n$ oproep tot aanbidding, 'n belydenis, toewyding aan God, 'n biddende erkenning van afhanklikheid van God of van God se teenwoordigheid (GKSA, 1997:11; Barnard, 1981:539 en Richter, 1998:49). 
As afwisseling sou die votum deur die gemeente of deur 'n kantory3 gesing kan word deur byvoorbeeld van die volgende liedere gebruik te maak: Psalm 15-2:1; 21-1:9; 24-1:2, 3; 24-2:2; 26-1:5; 29-1:1; 292:1, 5; 33-1:11; 36-1:2; 61-2:2, 3, 65-1:3; 89-2:2; 95-2:3; 113-1, -2:2; $121-1,-2: 1 ; 123-1,-2: 1$; Skrifberyming $1-2 ; 2-5$ en $15-1$.

\subsection{Seëngroet of groetseën}

By die seëngroet is God aan die woord en praat die liturg dus namens God wanneer hy die gemeente groet en seën. Die groetseën deur die liturg kan sinvol deur 'n gesonge "amen" by monde van die gemeente of liturgiese koor gevolg word (Strydom, 1994:299). Skrifberyming $13-1$ tot $13-4$ is uiters bruikbare toonsettings van die amen. Die amen funksioneer dan as 'n responsiewe toeëiening van die inhoud van die groetseën.

\subsection{Loflied}

'n Loflied wat implisiet of eksplisiet trinitaries is, kan hier gebruik word (Strydom, 1994:308). Verskillende variasies is moontlik as afwisseling, byvoorbeeld een volledige lied, twee of meer liedere in kombinasie, strofiese beurtsang tussen kantory en gemeente of tussen verskillende groeperings in die gemeente.

- Die volgende liedere kan vir die uiting van uitbundige lof dien: Psalm 8-1, -2; 9-1, -2; 18(2)4-1, -2; 29-1, -2; 33(2)-1, -2; 47-1, -2; $48-1,-2 ; 66-1,-2 ; 68-1 ; 75-1,-2 ; 89-1,-2 ; 92(1)-1,-2 ; 95-1,-2$; 96-1, -2; 98-1, -2; 99-1, -2; 100-1, -2; 103-1, -2; 107(2)-1, -2; 118$1,-2 ; 146-1,-2 ; 147(2)-1,-2 ; 148-1,-2 ; 149-1,-2$ en $150-1,-2$ asook Skrifberyming $1-2 ; 2-2 ; 3-3 ; 4-6$ en 18-3.

- Aanbiddingsliedere kan afwisselend saam met lofliedere gebruik word. Voorbeelde hiervan is: Psalm 5-2; 16-4; 23-1, -2; 24-1, -2; $31(2)-1,-2 ; 40-1: 3,5 ; 40-2: 3,5,6,13 ; 57-2,81-1,-2 ; 93-1,-2$; 104-1, -2; 105-1, -2; 106-2; 108-2; 111-1, -2; 113-1, -2; 115-1, -2; $123-1,-2 ; 138-1,-2 ; 139-1,-2 ; 145-1$, -2; Skrifberyming 1-1; 2-5; $2-6 ; 5-3 ; 6-2 ; 17-2$ en 18-1. Sommige van hierdie aanbiddingsliedere sal ook as Sanctus, of die beskrywing van God as die driemaal Heilige, kan dien.

3 'n Kantory is 'n liturgiese sanggroep wat plaasvervangend vir 'n kantor namens die gemeente of namens die liturg aan die liturgiese dialoog deelneem.

$4 \quad$ Waar meer as een melodie by 'n psalm afgedruk is, word die voorkeur-melodie as volg tussen hakies aangedui: Psalm 107(1). 


\section{Verootmoediging- en versoeningsdiens}

\subsection{Die wet}

Indien die wet as kenbron van die sonde funksioneer, sou dit vóór die skuldbelydenis kon pas (vgl. ook 2.4).

\subsection{Skuldbelydenis (Kyrie eleison)}

Die skuldbelydenis kan alleen op 'n oproep daartoe volg (Strydom, 1994:309). Calvyn het byvoorbeeld 'n oproep tot skuldbelydenis vóór die skuldbelydenisgebed en die dekaloog geplaas (Strydom, 1994:296).

- Sommige liedere wat as 'n oproep tot skuldbelydenis gebruik kan word, is: Psalm 14-2:1 tot 3, 50-1:8 tot 10; 50-2:3, 6 tot 8 en 532:1 tot 3 asook Skrifberyming 9-1 en 9-2.

- Daar is verskeie psalms wat gesamentlik deur die gemeente as skuldbelydenis gebruik kan word, byvoorbeeld: Psalm 19-1:7; 19$2: 5 ; 19-4: 5 ; 25-1: 3,5 ; 25-2: 4,5 ; 38-1: 1,5 ; 38-2: 7 ; 39-1: 5 ; 51-1$, - 2; 6-1:2; 65-2:1; 79-1:5(2); 79-2:6(2); 106-2:3; 130-1, -2(2):1 en 130-3(2):2 of Skrifberyming 9-3; 2-1:1 tot 2 en 9-6.

\subsection{Vryspraak (Absolusie)}

Die vryspraak volg gewoonlik direk op die verootmoediging en skuldbelydenis. Die essensie daarvan is die belofte van vergifnis en troos vir elkeen wat in opregte berou en met 'n ware geloof in Christus hulle sondes bely (Barnard, 1981:550).

Die liturg sou ter wille van afwisseling sommige verse uit die psalmboek as vryspraak kon lees of die gemeente sou dit as aanvaarding van God se vryspraak kon sing. Liedere wat byvoorbeeld die vryspraak verwoord, is Psalm 26-2:3; 32-1:1; 32-2:1 tot 2; 103-1:2 en 103-2:4, 5 asook Skrifberyming 11-1:1, 2 en 11. Besonder treffend is die woorde en melodie van Lied 482, waarvan die teks op Hosea 14:2-7 gebaseer is. Dit kan sag eenstemmig deur 'n kantory of liturgiese koor gesing word.

\subsection{Loflied op vryspraak (Gloria)}

Die tradisionele Gloria in excelsis is voorheen hier gebruik (Müller, 1988:67), maar 'n loflied wat die hoogste eer van God verkondig, sou ook gebruik kan word. 
- Die volgende lofliedere of trinitariese liedere kan oorweeg word: Psalm 29-1, -2:1; 33-1, -2:1-2; 34-1, -2:1-2; 65-1, -2:1; 66-1, -2:1; $100-1,-2: 1 ; 103-1,-2: 1$ asook Skrifberyming $1-1 ; 1-2 ; 1-3$ en 1-4. Veral Skrifberyming 3-3; 4-6 of die refrein van Lied 364, Gloria in excelsis Deo! (Ere aan God in die hoogste!) sou treffend aangewend kan word.

- Verdere voorbeelde van gepaste gemeentelike response op die genadeverkondiging is die volgende (vgl. ook 5.4): Psalm 9-1:1, 10; 9-2:1, 3, 5; 13-2:3; 18(2)-1:20; 28-1:6, 7; 28-2:4, 5; 31-1:5, 15, $17 ; 32-1: 1,6 ; 32-2: 2 ; 57-1: 5 ; 57-2: 4 ; 59-1: 10 ; 86-2: 4 ; 103-2: 5$; $116-1: 2,3,7 ; 116-2: 2,3$, 5 en $131-1: 2,3$.

- Die volgende is uit die Evangelies-Lutherse tradisie aangepas:

- Die liturg sing of lees die eerste vier reëls van Skrifberyming 4-6: "Ere aan God in die hoogste!" Indien die liturg verkies om dit voor te lees, speel die orrel saggies die ooreenstemmende melodiese gedeelte.

- Die liturgiese koor, kantory of gemeente antwoord deur die lied te voltooi.

- Die liturg sluit af met die lees van 1 Timoteus 1:17: "Aan Hom wat vir ewig Koning is, die onverganklike, onsienlike, enigste God, kom toe die eer en die heerlikheid tot in alle ewigheid! Amen" (Evangelisches Gesangbuch, 1994:179).

\subsection{Die wet (Dekaloog)}

Die wet kan op verskilllende wyses liturgies funksioneer deur die beklemtoning wat daaraan gegee word.

- Indien die wet as kenbron van die sonde aangewend word (GKSA, 1997:16), sou dit gepas wees dat elke gebod of tafel van die wet deur 'n Kyrie eleison, of smeekroep om God se genade gevolg word. Die volgende liedere kan as voorbeelde dien: Psalm $4-2: 1 ; 5-1: 1 ; 5-2: 1 ; 6-1: 1-5 ; 6-2: 1-3 ; 9-1: 9 ; 9-2: 7 ; 13-1: 3 ; 13-2: 2$; 28-1, -2:1-2; 57-2:1; 61-2:1; 70-2:4; 86-2:1-2; 88-1:2 en 130(2)-1, $-2: 1$. 'n Strofe uit 'n gepaste lied van skuldbelydenis kan ook goed gepas wees (Strydom, 1994:68; vgl. ook 4.2).

- By geleentheid kan die wet God se wil as maatstaf vir 'n heilige lewe verwoord. Hierdie beklemtoning kan deur die volgende liedere oorgedra word: Psalm 1-1, -2; 4-1; 15-1, -2; 18-1:10-12; $19-1: 5-7 ; 19-2: 3-5 ; 19-4: 3-4 ; 24-1,-2: 2-3 ; 25-1: 2,4,6,7 ; 25-2: 2-$ 
$3 ; 26-1,-2 ; 27-2: 4-5 ; 32-2: 4 ; 34-1: 6,8 ; 37-2: 3,12,15 ; 40-1: 4 ; 40-$ $2: 7,8,13 ; 71-2: 2,3,6,7 ; 86-2: 4 ; 112-1,-2 ; 119-1: 4,5,14$ en $119-2: 3,7$.

- Wanneer die wet as lewensreël vir 'n dankbaarheidslewe gebruik word, is die gesonge wet veral gepas (Strydom, 1994:69). Die gesonge dekaloog kan as tiperend van die reformatoriese liturgiese tradisie beskou word (Müller, 1988:69). In hierdie geval kan Psalm 1-1, -2; 15-1, -2; 119-2:1, 2, 7, 20 en 25; 141-1, -2:2-5 asook Skrifberyming 9-1 of 9-2 as plaasvervangend vir die wet funksioneer. Ter afwisseling sou 'n beryming van die saligsprekinge, Skrifberyming 11-3; 11-4, of van 1 Korintiërs 13 , Skrifberyming 9-4 of 9-5, gebruik kan word. By liedere met baie of lang strofes kan dit 'n probleem word om die konsentrasie van die gemeente te behou. Beurtsang kan by hierdie liedere help om die spanningslyn te handhaaf, byvoorbeeld: almal sing strofe 1, mans, dames en kinders om die beurt strofes 2 en 3 en almal die slotstrofe (Strydom, 1994:310-311).

- Nadat die wet as reël vir 'n lewe van dankbaarheid aangehoor is, kan gemeentesang hierdie heilsfeite dieper laat insink. Psalm 32$1: 3 ; 32-2: 4 ; 73-2: 5 ; 79-2: 9 ; 101-1: 1,4 ; 101-2: 1$ tot 3; 119-1:12, $20,47,48,53,60 ; 119-2: 2,4,8,14,17,19,27 ; 128-1,-2: 1 ; 139-$ $1: 12 ; 139-2: 11 ; 141-1: 2$ tot 4 of 141-2:2-5 kan vir dié doel aangewend word.

- 'n Uitbreiding van die voorafgaande sou wees om byvoorbeeld 'n psalm in kombinasie met die dekaloog te sing. Na elke gebod word twee reëls van die psalm soos volg gesing: gemeente sing Psalm $25-1,-2: 2$ reëls 1 en 2; voorganger lees die eerste gebod; gemeente sing Psalm -1, -2; 25:2 reëls 3 en 4; voorganger lees die tweede gebod, ensovoorts (Bingle, 2002).

\section{Die Woorddiens}

\subsection{Gebed om verligting deur die Heilige Gees (Epiklese)}

Epiklese beteken inroeping. Dit beklemtoon dus die gemeente se afhanklikheid van God (Müller, 1988:71). Hierdeur word God, die Heilige Gees, erken as die eintlike Inspireerder en Verklaarder van die goddelike Woord (GKSA, 1997:17).

- 'n Sinvolle liturgiese afwisseling sou wees om die epiklese-gebed deur die gemeente, of 'n lied as uitbreiding van die gesproke gebed, te laat sing (Richter, 1998:30). Die volgende liedere behoort hierdie gebed te kan verwoord of aan te vul: Psalm 19- 
$4: 3-4 ; 85-2: 3 ; 89-1: 6 ; 119-1: 7,19,39,51 ; 119-2: 7,14,18,22$ en 26 asook Skrifberyming 20-1:6.

- Indien die liturg in die gebed voorgaan, kan die gemeente of die liturgiese koor daarby aansluit deur die sing van Psalm 5-1, -2:1; 61-2:3 of $86-2: 4$ asook Skrifberyming $10-1$ of $10-2$.

\subsection{Die Skriflesing(s)}

Die Ou Testament, Sendbriewe en Evangelies is tradisioneel as Skriflesings gelees (Müller, 1988:72). Strydom (1994:300) gee 'n uiteensetting van 'n katoliek-gereformeerde diensorde vir Afrikaanssprekende, gereformeerde kerke waar hy die tradisionele liturgiese response ná die Skriflesings invoeg. Dit word voorts in volgorde behandel.

- Die Ou-Testamentiese lesing is deur die graduaalpsalm of -lied gevolg. Hierdie psalm of lied het dikwels 'n herhalende of refreingedeelte gehad wat deur verskillende faksies van die gemeente responsories gesing is. Voorbeelde van liedere wat op hierdie wyse kan funksioneer, is: Psalm 24-2; 42-1, -2, -3; 57-2; 59-1; 67$2 ; 80-1,-2 ; 107(2)-1,-2 ; 111-2 ; 112-2 ; 118-1$ en 136-1, -2. By sommige psalms sou 'n kernstrofe as antifoon, deur die liturg of liturgiese koor gesing kan word, terwyl die opeenvolgende strofes afwisselend deur verskeie faksies van die gemeente gesing word. 'n Psalmomdigting met kort strofes sou veral effektief kan werk. By Psalm 29-2 kan die volgorde omgeruil word sodat strofe 1, wat die "hemelinge" oproep om God se magtige verskyning te prys, telkens deur die gemeente plus die liturgiese koor aangehef word. Die opeenvolgende strofes kan dan deur die liturgiese koor alleen, of deur verskillende faksies van die gemeente gesing word, om telkens as inspirasie vir die grootste klank van die antifonies-herhalende eerste strofe te dien.

- Na die epistel- of sendbrieflesing is die Halleluja-akklamasie of Jubilus geplaas (Strydom, 1994:321). By gebrek aan 'n "Halleluja"-toonsetting, sou 'n kort vers uit 'n lofpsalm, byvoorbeeld Psalm 100-1, -2; 136-1, -2:1 of 148-2 gebruik kon word. Die uitroep "Halleluja", of "prys die Here", kom so dikwels in die psalms voor dat dit hoofsaaklik met die psalms geassosieer word. (Sien byvoorbeeld Psalm 115-117; Psalm 135 asook Psalm 146150.) Tydens advent en die lydenstyd is die Jubilus gewoonlik weggelaat (Strydom, 1994:323).

- Na die evangelielesing, wat tradisioneel as die hoogtepunt beskou is, het 'n doksologie gevolg. Dit behels gewoonlik 'n kort 
trinitariese of Christus-doksologie, maar die meeste lofpsalms sou hier gepas kon wees (Strydom, 1994:323): Psalm 33-1, -2; 66-1, -2; 89-1, -2; 92(1)-1, -2; 98-1, -2; 100-1, -2; 101; 103-1, -2; $104-1,-2 ; 105-1,-2 ; 107(2)-1,-2 ; 108-2 ; 111-1,-2 ; 113-1,-2$; $117-1,-2 ; 118-1,-2 ; 135-1,-2 ; 136-1,-2 ; 138-1,-2 ; 145-1,-2$; $146-1,-2 ; 147-1,-2 ; 148-1,-2 ; 149-1,-2$; of $150-1,-2$ asook Skrifberyming 1-2; 1-3:1; 1-4:1, 3; 3-2; 3-3; 3-4; 4-3; 4-8; 5-3; 7-1; 7-2:2 en 15-1.

Deur die verskillende Skriflesings telkens met 'n jubelende akklamasie op te volg, word die voorreg om God se Woord te kan aanhoor sowel as die sentraliteit daarvan beklemtoon.

\subsection{Die preek}

Die preek vind in noue samehang met die Skriflesing en die epiklesegebed plaas (Richter, 1998:560). Deelname van die gemeente tydens die preek behels aktiewe luister, verstaan, instemming en toeëiening van die boodskap (GKSA, 1997:22-23).

- Die betrokkenheid van die gemeente hoef egter nie net by swyende deelname te bly nie - toeëiening kan ook op afgespreekte plekke deur die gemeente of liturgiese koor deur middel van 'n amen of halleluja geskied.

- Ook die amen ná die preek hoef nie 'n woord te wees wat bloot deur die liturg uitgespreek word nie. Dit sou betekenisvol wees indien die gemeente hierdie amen gesamentlik uitspreek of sing (GKSA, 1997:24-25). Voorbeelde van die gesonge amen is afgedruk onder Skrifberyming 13-1; 13-2; 13-3 en 13-4.

\subsection{Die preeklied}

Wanneer die lied ná die preek 'n tipe samevatting van die preek is, funksioneer dit as 'n preeklied (Troskie, 2001:31). As antwoord van die gemeente, kan dit ook deel van die responsoria van die gemeente vorm (Barnard, 1981:576). In albei gevalle sal die lied dan by die tema van die preek aansluit of dit aanvul.

\section{Die sakramente}

Indien die sakramente bedien word, geskied dit volgens gereformeerde Nederlandse tradisie ná die preek. In sy Straatsburgse liturgie plaas Calvyn egter die sakramente later, ná die voorbiddingsgebed, offergawe en geloofsbelydenis. Sódoende dien hierdie elemente as liturgiese respons op die Woorddiens sowel as 'n 
voorbereidings- of brughandeling tot die tafeldiens (Strydom, 1994: 297).

\section{Antwoorddiens van die gemeente (Responsoria).}

Die essensie van die reponsoria is dat dit die antwoord van die gemeente op God se spreke deur die Woorddiens verwoord.

\subsection{Geloofsbelydenis (Credo)}

Die credo vorm deel van die antwoord van die gemeente. Dit is dus gepas dat die gemeente aktief daaraan sal deelneem (Barnard, 1981:573 en Müller, 1988:92). 'n Gemeente of die liturgiese koor sou die volledige credo kan sing deur gebruik te maak van die teks van Skrifberyming $12-1$ of $12-2$.

Die Psalmboek bevat liedere wat die kern van die geloofsinhoud verwoord, of 'n bevestiging van God se geloofwaardigheid bevat. Sommige van die volgende liedere sou by geleentheid plaasvervangend vir die credo of as 'n uitdrukking van geloofsvertroue, aangewend kan word: Psalm 3-2; 9-1:5-8; 9-2:3, 5; 13-2:3; 18(2)$1: 2,14 ; 18-2: 1,7,9 ; 27-1,-3: 6 ; 27-2: 7,8$ en $125-1,-2,-5: 1$. Verder is Skrifberyming 12-3 'n besonder bruikbare en treffende beryming van artikel 1 uit die Nederlandse Geloofsbelydenis op 'n bekende melodie.

Heelwat liedere uit die Psalmboek kan as 'n reaksie op die credo aangewend word. Die inhoud daarvan konkretiseer die geloof binne die praktiese lewensomstandighede van die gelowige. Voorbeelde hiervan is Psalm 5-2:5; 16-1, -2, -4:1; 62-1:1, 4; 62-2:1, 3, 4; 63-1:4; 63-2:2; 73-1:10 en 73-2:4 tot 5 asook Skrifberyming 14-1:1; 14-2 en 14-3:1 en 3.

Sommige praktiese wyses waarop sekere van die pasgenoemde Skrifberymings aangeleer en aangewend kan word, word vervolgens uiteengesit:

Die liturgiese koor kan gebruik word om die geloofsbelydenis volgens Skrifberyming 12-1 vir die gemeente aan te leer. Die volledige lied word aanvanklik deur die liturgiese koor gesing, terwyl die gemeente eers slegs instemmend luister en later genooi word om slegs die aanvang van die drie hoofdele saam te sing. Dit wil sê die gemeente sing saam met die koor: 
Ek glo in God, die Vader ...

En in Jesus Christus ...

Ek glo in die Heilige Gees ...

Indien dit gereeld op hierdie wyse gedoen word, sal die gemeente aanvanklik slegs sekere dele saamsing, maar uiteindelik die hele lied bemeester.

Skrifberyming 12-2 kan soos volg met die geloofsbelydenis van Nicea gekombineer word: Die gemeente sing strofe 1; die liturg lees die geloofsbelydenis van Nicea, beginnende met: "Hy is God uit God, lig uit lig, ..." en gaan aan tot by: "Hy het gely en is begrawe"; die gemeente sing strofe 3; die liturg gaan voort met: "Ons glo in die Heilige Gees ..." en gaan aan tot by: "Hy het deur die profete gespreek"; die gemeente sluit die geloofsbelydenis af met die sing van strofe 5 .

Skrifberyming 12-3 sou soms plaasvervangend vir die credo aangewend kan word.

\subsection{Gebed}

Die hoofgebed vorm deel van die saamgegroepeerde antwoord van die gemeente (GKSA, 1997:25) en daarom is dit juis belangrik dat die gemeente daarby betrek word. Aangesien die liturg normaalweg alleen aan die woord is, kan dit gebeur dat die gemeente passief toeluister sodat dit selde ' $n$ ware gesamentlike gebed is. Daarom is dit essensieel om wyses te vind waardeur die gemeente aktief kan deelneem.

Indien die gebed in temas onderverdeel word, sou die gemeente telkens gepas daarby kon aansluit. By elkeen van die afdelings sou die liturg byvoorbeeld in gebed kon voorgaan en dan telkens die gemeente deur middel van 'n lied betrek (Müller, 1988:98): die liturg gaan voor in die aanbidding van God; gemeentelike respons: "Here, ons aanbid U" of sing Psalm 100-2:2; die liturg lei die gemeente in danksegging; gemeentelike respons: "Here, daarvoor dank ons U", of sing Psalm 100-2:1 of 3; die liturg doen skuldbelydenis namens die gemeente; gemeentelike respons: "Here, wees ons genadig" of Psalm 65-2:1, 86-1, -2:1 (1e helfte); die liturg doen voorbidding en smeking; gemeentelike respons: "Here, verhoor ons" of Psalm 4-2:1, $5-1,-2: 1,86-1: 3$ of 4 en $86-2: 2$ of 3 .

'n Ander moontlikheid is dat die gemeente by die liturg aansluit by die aanvang of by die slot van die gebed ter intensivering daarvan. Liedere wat hier sou kon inskakel, is byvoorbeeld Psalm 4-2:1; 5-1, 
$-2: 1 ; 20-2: 1 ; 27-1,-3: 4 ; 28-1: 1$ tot $2 ; 28-2: 1,2,4 ; 40-2: 1,14 ; 57-1$, $-2: 1 ; 61-1,-2: 1 ; 69-1: 6 ; 69-2: 5 ; 70-2: 4 ; 88-1,-2: 2 ; 126-2: 1 ; 140-1: 4$; $140-2: 3 ; 141-1: 2$, 8; 141-2:1; 142-1, -2:1 en 143-1:1.

As afwisseling, kan die liturg die gebed op die gebruiklike wyse doen, gevolg deur 'n gesproke of gesonge Ons Vader, Skrifberyming 10-2 (Müller, 1988:99). Die gesamentlike gebed sou ook besonder paslik afgesluit kan word deur Skrifberyming 15-1, (Ef. 3:14-21) te sing - 'n gebed vír die gemeente, déúr die gemeente.

\section{Offergawes}

Die offergawe funksioneer as deel van die antwoorddiens en word daarom gewoonlik ná die preek geplaas (GKSA, 1997:30). Al is die gemeente fisies betrokke, gaan die ware betekenis van die offergawe dikwels verlore. Volgens Barnard (1981:575) behels die offergawe 'n antwoord en dus 'n nuwe oorgawe van die self aan die Here. Die kwaliteit van die gawe, wat dus die gesindheid van die gewer impliseer, is dus belangriker as die kwantiteit, dit wil sê die grootte of die hoeveelheid, daarvan.

Volgens ' $n$ steekproef deur Theron (1986:25-27) is die algemene karakter van die musiek by die tussenspel belangrik. Dit moenie die gedagtegang van die preek onderbreek nie, maar eerder 'n voortsetting daarvan wees - dus 'n rustige, mediterende atmosfeer skep.

\subsection{Orrelspel}

By die meeste gemeentes is dit gebruiklik dat orrelspel tydens die opneem van die offergawe plaasvind (Strydom, 1994:383). Alhoewel hierdie musiek nie liturgies noodsaaklik is nie, kan dit tog 'n sinvolle rol speel. Die mees betekenisvolle aanwending van orrelmusiek by die offergawe gebeur wanneer dit duidelik by die liturgie aansluit.

'n Eenvoudige verwerking, waar die melodie van 'n aansluitende en bekende kerklied duidelik waarneembaar is, kan baie waardevol wees. Indien die woorde die strekking van die preek kan aanvul, word dit des te meer sinvol. Die orrelspel kan dan dien om die meditasie van die gemeente te rig en te stimuleer (Strydom, 1994: 315). Op hierdie wyse kan die orrelspel selfs 'n verkondigende funksie vervul.

Die speel van 'n eenvoudige verwerking of improvisasie van die lied wat direk op die offergawe volg, is uiters ideaal (Conradie, 2002:17). Indien die woorde van die lied terselftertyd op 'n skerm in die kerk 
gegooi word, kan dit die spesifieke funksionaliteit daarvan verder beklemtoon. Wanneer daar nie 'n verwerking van die lied bestaan nie, kan die betrokke psalm of lied bloot met die melodie op 'n ander manuaal as solo gespeel word.

\subsection{Instrumentale musiek}

Instrumentale musiek kan tydens die offergawe as 'n nuwe, verfrissende klank tot eer van God opklink. (Vgl. byvoorbeeld Ps. 33:1-3.)

As 'n verrykende afwisseling sou 'n solo-instrument, wat die melodie of 'n eenvoudige versiering daarvan beklemtoon, saam met 'n harmoniese begeleiding deur die orrel gebruik kan word. 'n Instrumentale tussenspel deur 'n ensemble van houtblasers of strykinstrumente kan ook besonder effektief wees.

\subsection{Voorlesing}

Tydens die opneem van die offergawe kan 'n gepaste Skrifgedeelte, Skrifberyming of psalmomdigting by geleentheid gelees word. Indien dit begelei word deur sagte orrel- of instrumentale musiek, kan dit baie treffend wees.

\subsection{Gemeentesang}

'n Oordeelkundige keuse van liedere kan die betekenis van die offergawe verder beklemtoon. Strydom (1994:314) beskou die sing van lofliedere, dankseggingsliedere, offerliedere of toewydingsliedere as betekenisvol. Voorbeelde wat hier sal kan funksioneer, is: Psalm 5-1:3; 20-2:2; 27-2:4; 66-1:6; 66-2:4; 116-1:7, 10 en 116-2:5 tot 7. Müller (1988:100) gee die woorde van 'n lied soos dit in 'n Amerikaanse denominasie gebruik word: "Our Lord, this gift we bring to you ...". Die Christian Reformed Church sing "Praise God from whom all blessings flow" (Psalter Hymnal: 1987 no. 637 of 638). Die African Methodist Episcopal Church sing die parafrase van 2 Korintiërs 9:7: "Give as the Lord has prospered you." (African Methodist Episcopal, 1958:11).

\section{Die wegsending}

\subsection{Wegsendingslied}

Die gemeente word deur hierdie lied gehelp om die Woord toe te eien en dit as padkos saam te neem vir die werklike lewe (Müller, 1988:102). Die wegsendingslied slaan die brug tussen die 
gemeentelike erediens en die erediens van die lewe. Toepaslike wegsendingsliedere is byvoorbeeld: Psalm 25:2, 6; 105-1, -2:1; 1391:12; en 139-2:11 asook Skrifberyming 4-2:3 en 5.

\subsection{Die seën}

Volgens Barnard (1981:578) is die seën 'n wegstuur die lewe in waarmee daar ook 'n opdrag saamgaan - die verdere deurgee van die seën van God. Seënbedes, wat die gemeente vir mekaar kan toesing, is Psalm 5-1:10, 11; 67-1, -2:1; 115-2:7; 128-1:4; 134-1:3-4 en 134-2:2.

\subsection{Die amen}

Die amen ná die uitspreek van die seën, dien as toeëiening van God se genadige, liefdevolle guns. Dit spreek vanself dat dit deur die gemeente geuiter behoort te word. Om dit hardop deur die gemeente te laat te sê of te laat sing, kan net meer oortuigingskrag daaraan verleen (Müller, 1988:104). Vier toonsettings van die amen word gevind by Skrifberyming 13-1, 13-2, 13-3 en 13-4.

\subsection{Naspel}

'n Naspel gebaseer op die laaste lied kan daartoe bydra om die preekinhoud, soos verwoord in die preeklied of die missionêre bewustheid, soos onderstreep deur die wegsendingslied, verder te beklemtoon.

\section{Slot}

Hierdie artikel wil geensins voorgee om volledig die liturgiese moontlikhede vir die benutting van die Psalmboek van 2003 uit te put nie. Voorbeelde van liedere vir die verskillende elemente van die erediens word bloot as ' $n$ basis vir verdere, kreatiewe ontginning voorgestel. Die liturgiese voorstelle, soos in hierdie artikel uiteengesit, behoort dus slegs as uitgangspunt vir elke gemeente se individuele liturgiese behoeftes te dien.

\section{Geraadpleegde bronne}

AFRICAN METHODIST EPISCOPAL CHURCH. 1958. Word hymnal. Nashville: A.M.E. Sunday School Union.

BARNARD, A.C. 1981. Die erediens. Pretoria: NG Kerkboekhandel.

BINGLE, J.P. 2002. Mondelingse aanbeveling, 12 Oktober 2002.

BINGLE, J.P. 2003. Voorwoord tot Psalmboek. Wellington: NG Kerk-uitgewers.

CHANTS DE TAIZÉ. 2001. Taizé: Ateliers et Presses de Taizé. 
CONRADIE, M. 2002. Herontdek ... nuut verwerk: 41 liturgieë. Lyttelton Manor: Medpham Publikasies.

EVANGELISCHES GESANGBUCH. 1994. Evangelisch-Lutherischen Kirchen. Würzburg: Universitätsdruckerei.

GEREFORMEERDE KERKE IN SUID-AFRIKA. 1997. Ons kerke se lewe weerspieël in ons liturgie. Calvyn Jubileum Boekefonds.

GKSA

kyk GEREFORMEERDE KERKE IN SUID-AFRIKA

KLOPPERS, E.C. 1998. Bekendstelling van nuwe liedere: 'n proefsangbundel. Vir die musiekleier, 25:22-25.

KLOPPERS, E.C. 2002. Die kreatiewe inrigting van die liturgie. Vir die musiekleier, 29:12-18.

LIEDBOEK VAN DIE KERK. 2001. Wellington: NG Kerkuitgewers.

LOUW, J., VAN DER MERWE, H. \& ENGELBRECHT, F. 2002. Liedboeksleutel: 'n elektroniese multimedia-hulpmiddel vir die Liedboek van die kerk. Wellington: Lux Verbi.

MÜLLER, J. 1988. Die erediens as fees. Halfway House: NG Kerkboekhandel.

PSALMBOEK. DIE BERYMDE EN OMGEDIGTE PSALMS EN ANDER SKRIFBERYMINGS IN GEBRUIK BY DIE GEREFORMEERDE KERKE IN SUID-AFRIKA. 2003. Wellington: NG Kerkuitgewers.

PSALTER HYMNAL. 1987. Christian reformed church in North America. Grand Rapids: CRC Publications.

RICHTER, J. 1998. Het ons hart nie warm geword nie ...? Riglyne vir 'n gemeentelike eredienswerkgroep. Matieland: BUVTON.

STRYDOM, W.M.L. 1992. Eietydse erediensvernuwing in die gereformeerde kerke in Engeland en Europa. Vir die musiekleier, 28:25-31.

STRYDOM, W.M.L. 1994. Sing nuwe sange, nuutgebore: liturgie en lied. Bloemfontein: NG Sendingpers.

THERON, E. 1986. Hoe ervaar die gemeentelid die toevallige musiek in die erediens. 'n Steekproef. Vir die musiekleier, 11:25-27.

TROSKIE, A. 2001. Liedboek van die kerk: praktiese gebruik vir orrelis en leraar. Vir die musiekleier, 28:25-31.

VORSTER, J.M. 1996. Is die kerk funksioneel? Gedagtes oor Gereformeerde kerkvernuwing in 'n postmoderne konteks. Potchefstroom: Potchefstroomse Teologiese Publikasies.

\section{Kernbegrippe:}

gesonge liturgiese response

liturgiese verryking

Psalmboek van 2003

psalms en Skrifberymings in liturgie

\section{Key concepts:}

liturgical enrichment

Psalmbook of 2003

psalms and Sciptural versifications in liturgy

sung liturgical responses 
